\title{
Seasonal Growth and Nitrogen Uptake of Encore Azalea 'Chiffon' Affected by Nitrogen Availability and Containers
}

\author{
Tongyin $\mathrm{Li}^{1}$, Guihong Bi, and Richard L. Harkess \\ Mississippi State, MS 39762 \\ Additional index words. biocontainer, seasonal growth, Rhododendron
}

Department of Plant and Soil Sciences, Mississippi State University,

\begin{abstract}
Plant growth and nitrogen (N) uptake of Encore ${ }^{\circledR}$ azalea 'Chiffon' (Rhododendron sp.) grown in a traditional plastic container or a biodegradable container made from recycled paper were investigated over the 2013 growing season. Three hundred twenty 1-year-old azalea liners, grown in two types of containers, were fertilized twice weekly with $250 \mathrm{~mL}$ Nfree liquid fertilizer with no $\mathrm{N}$ or $15 \mathrm{~mm} \mathrm{~N}$ from ammonium nitrate $\left(\mathrm{NH}_{4} \mathrm{NO}_{3}\right)$. Biweekly from 10 May to 3 Dec., five plants from each $N$ rate and container type were selected randomly to measure plant height, widths, and leaf chlorophyll content in terms of soil-plant analysis development (SPAD) readings, and were then harvested destructively for nutrient analyses. Leaf SPAD readings and tissue $N$ concentration were influenced mostly by $N$ rate rather than container type, with $15 \mathrm{~mm} \mathrm{~N}$ producing greater values than the no-N treatment. Leaf SPAD readings increased from May to August and decreased from September to December. Using $15 \mathrm{~mm} \mathrm{~N}$, plastic containers generally resulted in similar or increased plant growth [plant growth index (PGI) and dry weight] and $N$ uptake from May to August as in biocontainers, with greater SPAD readings, leaf and root dry weights, stem and root $\mathrm{N}$ concentrations, and leaf and root $N$ content than biocontainers at some harvests. However, biocontainers resulted in greater PGI, dry weights, and $\mathrm{N}$ content (in leaves, stems, roots, and total plant) than plastic containers later in the season, from September to December. These differences appeared in September after plants grown in plastic containers ceased active growth in dry weight and $N$ uptake by the end of August. Plants grown in biocontainers had extended active growth from 13 Sept. to 9 Nov., resulting in greater tissue $N$ content and greater $N$ uptake efficiency. The biocontainers used in this study produced azalea plants of greater size, dry weight, and improved $\mathrm{N}$ uptake by increasing growth rate and extending the plants' active growth period into late fall. The beneficial effects likely resulted from greater evaporative cooling through container sidewalls and the lighter color of the biocontainers, and therefore led to lower substrate temperatures and improved drainage.
\end{abstract}

Azaleas are among the most popular ornamental crops in the United States. The market for azaleas in the United States was $\$ 18.9$ and $\$ 18.3$ million in 2014 and 2015, with $\approx 4.1$ and 3.69 million plants being sold in these 2 years, respectively (U.S. Department of AgricultureNational Agricultural Statistics Service, 2016). Azaleas are popular for their colorful blooms and various blossom forms. Encore ${ }^{\circledR}$ azaleas are a patented brand series of azaleas that bloom in spring, summer, and fall (Wilson Bros. Gardens,

Received for publication 20 Dec. 2018. Accepted for publication $3 \mathrm{Feb} .2019$.

This work was supported by the Mississippi Agriculture and Forestry Experiment Station and the U.S. Department of Agriculture National Institute of Food and Agriculture Hatch project MIS-249180.

We thank Robert E. "Buddy" Lee from Plant Development Services, Inc., for donating all the plant materials for this study.

Mention of a trademark, proprietary product, or vendor does not constitute a guarantee or warranty of the product by Mississippi State University and does not imply its approval to the exclusion of other products or vendors that also may be suitable.

${ }^{1}$ Corresponding author. E-mail: t1665@msstate. edu.
2018). Multiple blooming seasons require continuous plant growth and nutrient supply. Plant nutrient uptake is subject to a number of factors such as growth rate, climate, and cultivating conditions (Bi et al., 2007b; Gastal and Lemaire, 2002; Million et al., 2007; Scagel et al., 2007). Nutrient uptake varies among crops, between growing seasons, and between production sites (Chang et al., 2012; Pradubsuk and Davenport, 2010; Ristvey et al., 2007; Scagel et al., 2007). The nutrient requirement of a given species or cultivar also fluctuates within a growing season (Strik and Bryla, 2015), which is difficult to predict and has rarely been reported.

The optimal fertilization program relies on specific information regarding the nutrient requirements of a species or cultivar, plant growth stage, climatic conditions, and substrate composition (Cardarelli et al., 2010; Gómez-López et al., 2006; Mengel and Kirkby, 2001). Chang et al. (2012) reported $\mathrm{N}$ supply and climate fluctuations interacted to influence the growth and yield of Anthurium andraeanum Lind. They reported $\mathrm{N}$ supply to be the limiting factor during spring and summer, whereas climate conditions was the limiting factor during fall and winter in Taiwan, a subtropical climate (Chang et al., 2012). With sufficient $\mathrm{N}$ supply, the increase of $\mathrm{N}$ content in a plant was believed to be determined by the growth rate of plants rather than by different species or climatic conditions (Gastal and Lemaire, 2002).

Biodegradable containers, also referred as biocontainers, have been investigated in recent years as sustainable alternatives to conventional plastic containers (Hall et al., 2010; Nambuthiri et al., 2015; White, 2009). A variety of biocontainers made from materials such as peat, manure, coir, straw, and wood fiber have been evaluated and found to produce plants of comparable quality to traditional plastic containers (Koeser et al., 2013a; Kuehny et al., 2011). Depending on the hydrophilic or hydrophobic materials that constitute the biocontainers, plants grown in biocontainers have various water-use characteristics, with some of them requiring more water or more frequent irrigation than plastic containers (Evans and Karcher, 2004; Evans et al., 2010; Koeser et al., 2013b). Water availability between irrigation events may then influence nutrient availability to the plant in the substrate (Scagel et al., 2011). The porous nature of the sidewalls of some biocontainers has resulted in greater water use, but increased evaporation was believed to help reduce substrate temperature, which is a beneficial feature at locations where summer heat stress may be a problem for plant growth or survival (Nambuthiri et al., 2015; Wang et al., 2015).

We found in our previous study that the paper biocontainer increased the PGI, root length and surface area, dry weight, and plant $\mathrm{N}$ uptake in Encore ${ }^{\circledR}$ azalea 'Chiffon' with $\mathrm{N}$ rates of 15 and $20 \mathrm{~mm}$ compared with traditional plastic containers ( $\mathrm{Li}$ et al., 2018). However, seasonal growth and the nutrient uptake pattern of azalea plants grown in biocontainers vs. plastic containers remain unknown. Therefore, the objectives of this study were 1) to investigate the plant growth and $\mathrm{N}$ uptake pattern of Encore $^{\circledR}$ azalea 'Chiffon' during a growing season, 2) to compare plant growth and $\mathrm{N}$ uptake of plants grown in conventional plastic containers with those grown in paper biocontainers, and 3) to identify the timing when difference in growth and $\mathrm{N}$ uptake may occur.

\section{Materials and Methods}

Plant culture and treatments. Three hundred twenty 1-year-old liners of Encore ${ }^{\circledR}$ azalea 'Chiffon' of uniform size were transplanted into two types of 1-gal containers in Apr. 2013. One is a conventional black plastic container (GL 400; Nursery Supplies ${ }^{\circledR}$, Chambersburg, PA; top diameter, $17.78 \mathrm{~cm}$; bottom diameter, $18.10 \mathrm{~cm}$; volume, $3.785 \mathrm{~L}$ ) and the other is a biodegradable container made from a mix of recycled paper (Western Pulp Products Co., Corvallis, OR; $7 \times 7$ round; interior top diameter, $18.7 \mathrm{~cm}$; bottom diameter, $14.9 \mathrm{~cm}$; height, $17.1 \mathrm{~cm}$; volume, $3.90 \mathrm{~L}$ ). All plants were grown outdoors under full-sun conditions at Mississippi State University (lat. $33^{\circ} 27^{\prime} \mathrm{N}$, long. $88^{\circ} 47^{\prime} \mathrm{W}$; U.S. Department of Agriculture hardiness zone $8 \mathrm{a}$ ). The dwarf variety of Encore $^{\circledR}$ azalea 'Chiffon' with a slow growth 
rate was selected for this study to accommodate plant growth for one growing season in 1-gal containers. Pine bark, adjusted with $1 \mathrm{lb} /$ yard lime (Soil Doctor Pelletized Lawn Lime; Oldcastle, Atlanta, GA), was used as growing substrate. Each azalea plant was fertilized twice weekly with $250 \mathrm{~mL} \mathrm{~N}$-free fertilizer, $0 \mathrm{~N}$ 2.6P-22.4K (Cornell No. N Eq. 0-6-27; GreenCare Fertilizers, Kankakee, IL) (Li et al., 2019), with either no $\mathrm{N}$ or $15 \mathrm{~mm}$ (210 mg. $\mathrm{L}^{-1}$ ) $\mathrm{N}$ from $\mathrm{NH}_{4} \mathrm{NO}_{3}$ from 23 Apr. (14 d after transplanting) to 15 Sept. 2013 (159 d after transplanting), totaling 42 fertilization events with $52.5 \mathrm{mg} \mathrm{N}$ delivered at each time. The no-N treatment served as control to demonstrate there was not a considerable amount of $\mathrm{N}$ available to the azalea plants in the substrate or from any other sources within the experiment setting. In addition, $\mathrm{N}$ content in plants receiving no $\mathrm{N}$ also served as a baseline that was used in calculations to estimate $\mathrm{N}$ uptake from fertilizer with the $15-\mathrm{mm} \mathrm{N}$ treatment.

All plants were drip-irrigated daily on the same irrigation zone to replace daily water use plus a $15 \%$ leaching fraction. Daily water use amount was determined gravimetrically as described by Li et al. (2018). Irrigation amount was corrected during the growing season by averaging daily water use of five plants fertilized with $15 \mathrm{~mm} \mathrm{~N}$ grown in both plastic containers and biocontainers. Growth response of azalea plants was monitored closely during the growing season to avoid any possible water stress and therefore a confounding effect of irrigation on experimental factors.

Plant harvest and data collection. Five plants were selected randomly from each $\mathrm{N}$ rate and container type (total of 20 plants) and were harvested destructively roughly every 2 weeks, with the first harvest on 10 May (31 d after transplanting) and the last harvest (16th harvest) on 3 Dec. 2013 (238 d after transplanting). Each plant was cleaned with deionized water free from substrate, and separated into leaves, stems, and roots. All samples were then oven-dried at $60{ }^{\circ} \mathrm{C}$. The dry weight of each sample was measured at each harvest. Before each destructive harvest, the selected plants were measured for relative leaf chlorophyll content estimated by SPAD reading, plant height, and width (greatest width = width 1 ; width perpendicular to width $1=$ width 2 ). The PGI was calculated as the average of plant height, width 1 , and width 2 . Three fully expanded new leaves were selected on a given plant to measure leaf chlorophyll content using a chlorophyll meter (SPAD 502 Plus; Konica Minolta, Tokyo, Japan). An average of the three readings from the three leaves was calculated to represent leaf chlorophyll content of a given plant.

Tissue $N$ analyses. After being ovendried, all samples were ground to pass through a 1-mm mesh (\#20 mesh) using a Wiley mill for nutrient analyses. The Kjeldahl method was used to determine $\mathrm{N}$ concentration in each plant sample using 0.1 g dry sample (Bremner, 1965).

Calculations. Total plant dry weight was calculated by summing dry weights of leaves,
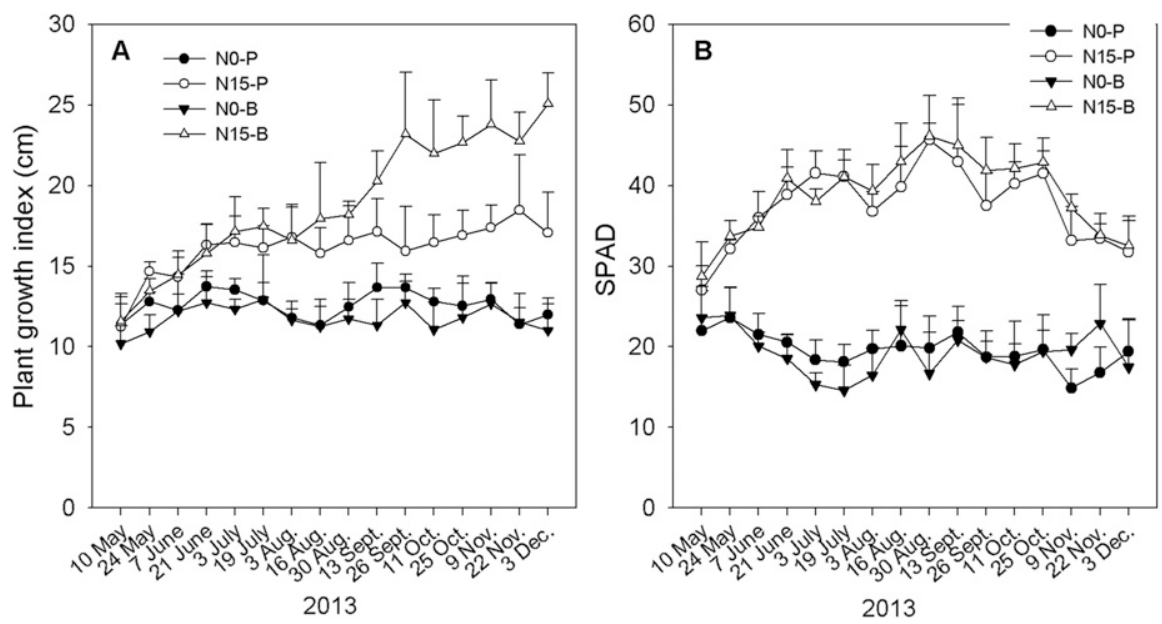

Fig. 1. Plant growth index (PGI) (A) and leaf soil-plant analysis development (SPAD) (B) of Encore ${ }^{\circledR}$ azalea 'Chiffon' plants fertilized with no $\mathrm{N}(\mathrm{N} 0)$ or $15 \mathrm{~mm} \mathrm{~N}(\mathrm{~N} 15)$ from $\mathrm{NH}_{4} \mathrm{NO}_{3}$ and grown in plastic containers (P) or paper biocontainers $(\mathrm{B})$ over the 2013 growing season. $\mathrm{PGI}=[\mathrm{Plant}$ height + Width 1 (widest point) + Width 2 (perpendicular width)]/3. PGI and SPAD were measured biweekly from 10 May to 3 Dec. 2013. Error bars suggest SD.
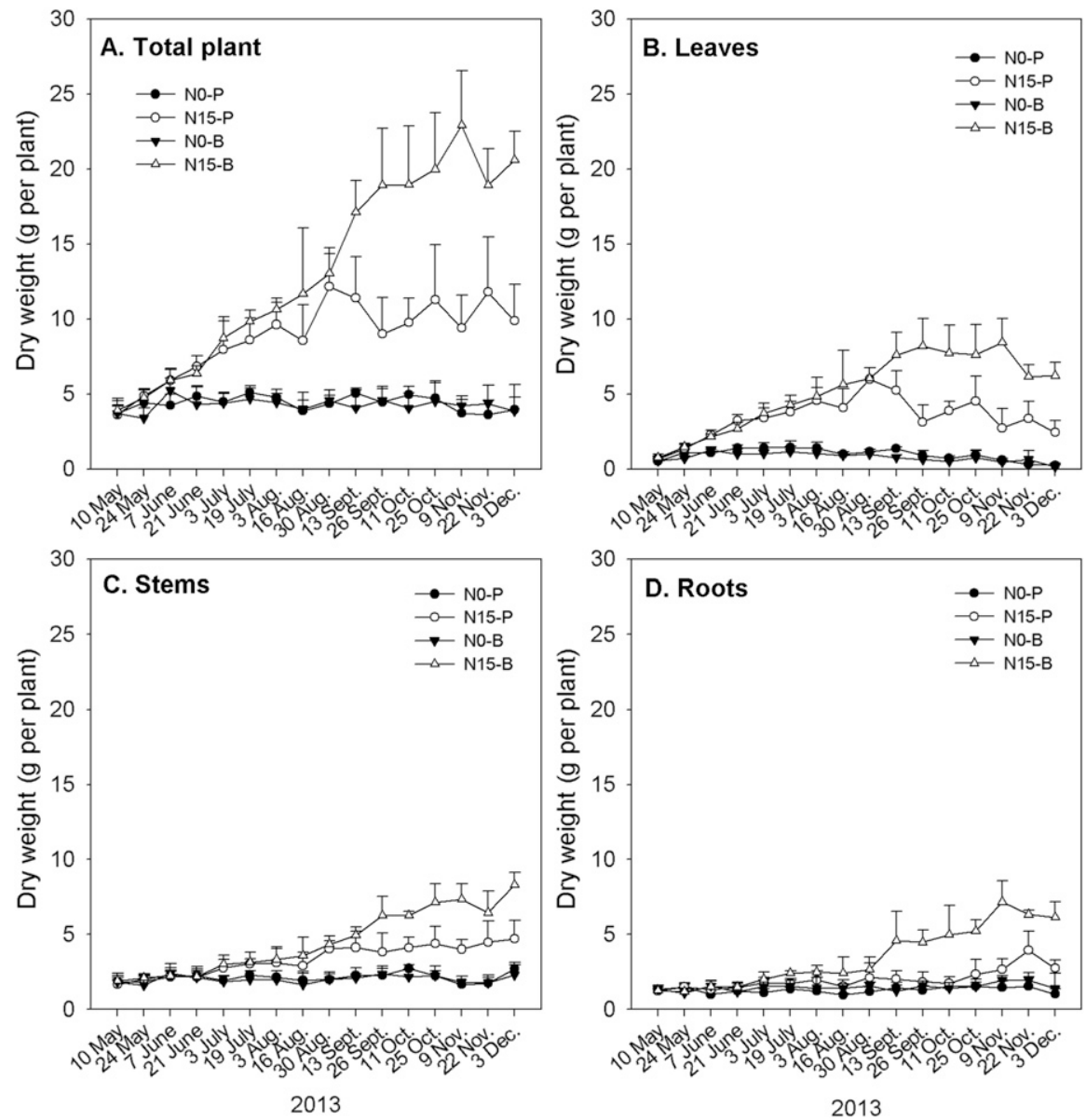

Fig. 2. Total plant dry weight (A) and dry weight of leaves $(\mathbf{B})$, stems $(\mathbf{C})$, and roots $(\mathbf{D})$ of Encore ${ }^{\circledR}$ azalea 'Chiffon' fertilized with no $\mathrm{N}(\mathrm{N} 0)$ or $15 \mathrm{~mm} \mathrm{~N}(\mathrm{~N} 15)$ from $\mathrm{NH}_{4} \mathrm{NO}_{3}$ and grown in plastic containers (P) or paper biocontainers (B) over the 2013 growing season. Plants were harvested destructively biweekly from 10 May to 3 Dec. 2013 for dry weight measurements. Error bars suggest SD.

stems, and roots of a given plant. Nitrogen content in leaves, stems, or roots was calculated by multiplying tissue $\mathrm{N}$ concentration by sample dry weight. Total plant $\mathrm{N}$ content was estimated by summing $\mathrm{N}$ content in leaves, stems, and roots. Average plant $\mathrm{N}$ concentration was calculated using total plant $\mathrm{N}$ content divided by total plant dry weight.

As a result of the slow growth rate of the Encore $^{\circledR}$ azalea 'Chiffon', plant growth rate in 
terms of dry weight accumulation (measured as milligrams per day) was calculated between every two harvests (4 weeks), which was estimated as the average change in dry weight (or biomass) of each structure (leaves, stems, or roots) or the entire plant divided by the number of days between the two harvests. Total $\mathrm{N}$ uptake from the fertilizer was estimated by subtracting total $\mathrm{N}$ content of plants fertilized with no $\mathrm{N}$ grown in a certain container type from the total $\mathrm{N}$ content of those receiving $15 \mathrm{~mm} \mathrm{~N}$ at each harvest. Nitrogen uptake efficiency (measured as a percentage) of plants fertilized with $15 \mathrm{~mm} \mathrm{~N}$ grown in a certain container type was calculated as the proportion of $\mathrm{N}$ uptake from fertilizer to the total applied $\mathrm{N}$ fertilizer on a given date (Bi et al., 2007a). Nitrogen uptake rate (measured as milligrams per day) was also calculated between two harvests and was estimated as the difference in $\mathrm{N}$ content, in a specific structure type or the entire plant divided by the number of days between the two harvests. All data calculations were conducted using Microsoft Excel (Version Microsoft Office Professional Plus 2016; Microsoft Corporation, Redmond, MA).

Experimental design and statistical analyses. This experiment was a factorial arrangement of treatment in a completely randomized design. The two treatment factors were $\mathrm{N}$ rate $(0$ and $15 \mathrm{~mm} \mathrm{~N})$ and container type (plastic and biocontainer). Harvest time (16 harvests) was considered a repeated measure. Significance of main effects $(\mathrm{N}$ rate or container type) and their interactions at each harvest date were determined using analysis of variance (ANOVA) with the Proc GLM procedure of SAS (version 9.4, SAS Institute, Cary, NC). Where indicated by ANOVA, means were separated among treatment comsignificant difference test at $P<0.05$. Means were not compared across different harvests.

\section{Results}

Plant growth index. There was no difference in PGI among treatments at the first harvest on 10 May ( $20 \mathrm{~d}$ after fertilization treatment) (Fig. 1A). From 24 May (second harvest) to 30 Aug. (ninth harvest), plants fertilized with $15 \mathrm{~mm} \mathrm{~N}$ had a greater PGI than those with no N. Container type did not influence PGI for the first nine harvests from 10 May to 30 Aug. The interaction between container type and $\mathrm{N}$ rate became significant from 13 Sept. (10th harvest) to 3 Dec. (16th harvest), except on 22 Nov. (15th harvest). When the interaction was significant, biocontainers resulted in plants with a greater PGI than plastic containers with $15 \mathrm{~mm} \mathrm{~N}$. Container type did not cause changes in the PGI when plants received no N.

Leaf chlorophyll content. For leaf chlorophyll content estimated as SPAD readings, there was no interaction between container type and $\mathrm{N}$ rate at any of the 16 harvests (Fig. 1B). Plants fertilized with $15 \mathrm{~mm} \mathrm{~N}$ had greater SPAD readings than those receiving no $\mathrm{N}$ over the growing season. Plastic containers produced plants with greater SPAD binations at each harvest by Fisher's least readings than biocontainers on 3 July (fifth harvest). However, biocontainers resulted in tainers on 9 Nov. and 22 Nov.- the 14th and 15th harvests, respectively. Except for these three harvests, container type did not influence leaf SPAD readings. During the growing season, leaf SPAD readings in plants fertilized with $15 \mathrm{~mm} \mathrm{~N}$ increased from 10 May to 30 Aug. and decreased from $30 \mathrm{Aug}$. to $3 \mathrm{Dec}$. The greatest SPAD reading was found on 30 Aug. in plants fertilized with $15 \mathrm{~mm} \mathrm{~N}$ grown in biocontainers. The lowest SPAD reading was found on 19 July in plants fertilized with no $\mathrm{N}$ grown in biocontainers.

Plant dry weight. Total plant dry weight was similar among all treatment combinations on 10 May (first harvest) (Fig. 2A). An $\mathrm{N}$ rate of $15 \mathrm{~mm}$ resulted in greater total plant dry weight of azalea from 24 May (second harvest) to 30 Aug. (ninth harvest). Two container types resulted in similar total plant dry weight for the first nine harvests. The interaction between container type and $\mathrm{N}$ rate was significant from 13 Sept. to 3 Dec. With $15 \mathrm{~mm} \mathrm{~N}$, biocontainers produced azalea plants with the greatest total dry weight. There was no difference in total plant dry
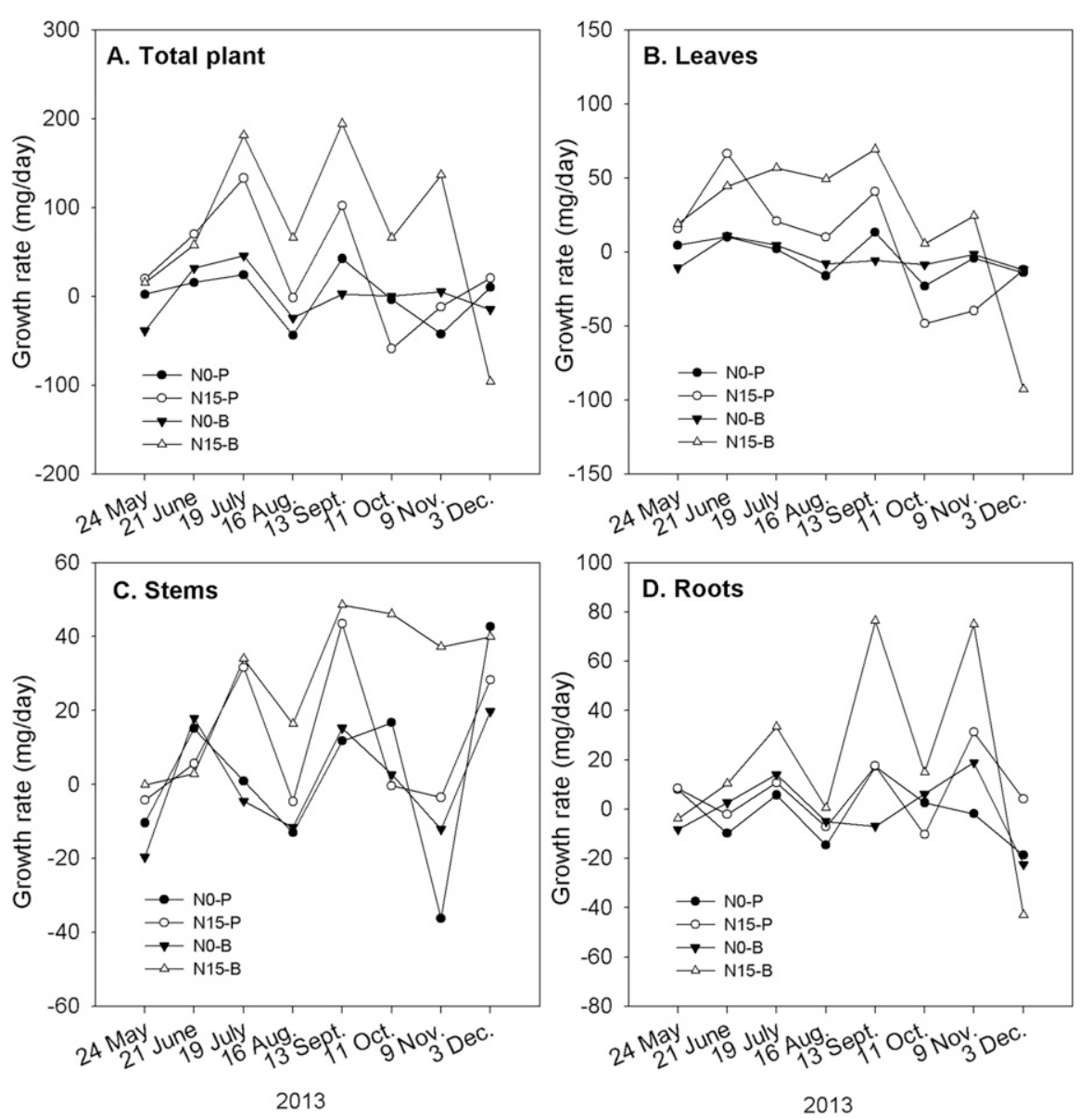

Fig. 3. Growth rate in terms of dry weight accumulation in the entire plant (A), leaves $(\mathbf{B})$, stems $(\mathbf{C})$, and roots (D) of Encore ${ }^{\circledR}$ azalea ‘Chiffon' fertilized with no N (N0) or $15 \mathrm{~mm} \mathrm{~N}(\mathrm{~N} 15)$ from $\mathrm{NH}_{4} \mathrm{NO}_{3}$ and grown in plastic containers (P) or paper biocontainers (B) over the 2013 growing season. Growth rate was calculated on a 4-week interval as a result of the slow growth rate of this cultivar, and was estimated as the average change in dry weight of the entire plant or each structure (leaves, stems, or roots) divided by the number of days in between.

weight between container types with no $\mathrm{N}$ treatment.

The dry weight of leaves and roots shared a similar trend as total plant dry weight, with no difference in leaf or root dry weight among all treatment combinations on 10 May (Fig. 2B and D). An $\mathrm{N}$ rate of $15 \mathrm{~mm}$ resulted in greater leaf dry weight from 24 May (second harvest) to 30 Aug. (ninth 24 (a), and greater root dry weight from significant effect from container type except that plastic containers resulted in greater leaf dry weight on 21 June and greater root dry weight on 24 May compared with biocontainers. Later in the growing season, there and $\mathrm{N}$ rate in leaf dry weight from 13 Sept. to 3 Dec. (last seven harvests) and in root dry weight from 26 Sept. to 3 Dec. (last six $\mathrm{N}$ rate interaction the container type and $15 \mathrm{~mm} \mathrm{~N}$ resulted in the greatest leaf or root dry weight.

Stem dry weight was similar among all treatment combinations on 10 May (first harvest), 7 June (third harvest), and 21 June (fourth harvest) (Fig. 2C). The interaction greater SPAD readings than plastic conwas an interaction between container type 
between $\mathrm{N}$ rate and container type was significant on 26 Sept., 11 Oct., 25 Oct., 9 Nov., and 3 Dec., sharing similar trends with leaf, root, or total plant dry weight. Except for the five harvests mentioned, $15 \mathrm{~mm} \mathrm{~N}$ produced greater stem dry weight than the no-N treatment, with no container effect.

Plant growth rate in terms of dry weight accumulation. The growth rate of plants receiving no $\mathrm{N}$ remained between $-43.9 \mathrm{mg} / \mathrm{d}$ and $45.6 \mathrm{mg} / \mathrm{d}$ in terms of the increase/ decrease in plant total dry weight during the experiment duration (Fig. 3). When fertilized with $15 \mathrm{~mm} \mathrm{~N}$, plants grown in biocontainers generally had a similar or greater growth rate compared with plants grown in plastic containers. During the growing season, the biocontainer-grown plants had three flushes of growth, from 21 June to 19 July, from 16 Aug. to 13 Sept., and from 11 Oct. to 9 Nov. (Fig. 3A). In comparison, plastic containergrown plants had two flushes of growth concurrent with the timing of the first two flushes of plants grown in biocontainers. During the first two flushes of growth, biocontainers resulted in growth rates of 183.4 $\mathrm{mg} / \mathrm{d}$ and $194.0 \mathrm{mg} / \mathrm{d}$ compared with 132.2 $\mathrm{mg} / \mathrm{d}$ and $100.1 \mathrm{mg} / \mathrm{d}$ of plants grown in plastic containers, respectively. During the period from 11 Oct. to 9 Nov., biocontainergrown plants were still accumulating dry weight at a rate of $138.1 \mathrm{mg} / \mathrm{d}$, whereas plants in plastic containers were decreasing in dry weight at a rate of $11.9 \mathrm{mg} / \mathrm{d}$. Dry weight of plants grown in biocontainers started to decrease after 9 Nov., causing a negative growth rate on $3 \mathrm{Dec}$. Azalea plants grown in plastic containers accumulated leaf dry weight at a rate of $66.5 \mathrm{mg} / \mathrm{d}$ compared with $44.2 \mathrm{mg} / \mathrm{d}$ in biocontainers early during the growing season, from 24 May to 21 June (Fig. 3B). However, leaf growth rate of plants grown in biocontainers ranged from 49.1 to $69.4 \mathrm{mg} / \mathrm{d}$ from 21 June to 13 Sept. compared with 10.1 to $40.9 \mathrm{mg} / \mathrm{d}$ in leaves of plants grown in plastic containers. Plants grown in plastic containers started to decrease in leaf dry weight after 13 Sept. However, plants grown in biocontainers continued accumulating leaf dry weight, but at a lower rate, from 13 Sept. to 9 Nov., and then started to decrease toward 3 Dec. Plants receiving no N grown in plastic containers or biocontainers had a leaf growth rate that ranged from -23.1 $\mathrm{mg} / \mathrm{d}$ to $13.3 \mathrm{mg} / \mathrm{d}$ throughout the growing season.

Stem growth rate in plants fertilized with $15 \mathrm{~mm} \mathrm{~N}$ grown in plastic containers or biocontainers had two peaks - from 21 June to 19 July and from 16 Aug. to $13 \mathrm{Sept}$ - -with growth rates of 31.6 and $43.5 \mathrm{mg} / \mathrm{d}$ in plastic containers, and 34 and $48.6 \mathrm{mg} / \mathrm{d}$ in biocontainers, respectively (Fig. 3C). Stem growth rate in plastic containers dropped sharply after 13 Sept., but maintained at 37.2 to $46.1 \mathrm{mg} / \mathrm{d}$ in biocontainers from 11 Oct. to 3 Dec.

Root growth rate in plants receiving no $\mathrm{N}$ ranged from -18.7 to $18.8 \mathrm{mg} / \mathrm{d}$ throughout the growing season (Fig. 3D).

In plants fertilized with $15 \mathrm{~mm} \mathrm{~N}$ and grown in biocontainers, a small growth flush occurred in roots from 21 June to 19 July, with a growth rate of $33.3 \mathrm{mg} / \mathrm{d}$, and two large flushes of growth occurred from 16 Aug. to 13 Sept. and from 11 Oct. to 9 Nov., with growth rates of 76.4 and $74.8 \mathrm{mg} / \mathrm{d}$, respectively. There were two root growth flushes in plants fertilized with $15 \mathrm{~mm} \mathrm{~N}$ and grown in plastic containers-from 16 Aug. to 13 Sept. and from 11 Oct. to 9 Nov.with growth rates of 18.6 and $31.4 \mathrm{mg} / \mathrm{d}$, respectively.

Tissue $N$ concentration. In general, the $\mathrm{N}$ rate of $15 \mathrm{~mm} \mathrm{~N}$ resulted in greater tissue $\mathrm{N}$ concentration than no $\mathrm{N}$ treatment during the growing season, in leaves (at all 16 harvests), stems (at 11 harvests), and roots (at 11 harvests), and averaged in the plant (at 15 harvests) (Fig. 4). The interaction between container type and $\mathrm{N}$ rate was significant at four harvests in stems (on 3 Aug., 13 Sept., 11 Oct., and 25 Oct.) and roots (on 13 Sept., 26 Sept., 11 Oct., and 9 Nov.), and at one harvest averaged in the plant (on 25 Oct.). When the interaction was significant, plants fertilized with $15 \mathrm{~mm} \mathrm{~N}$ and grown in plastic containers had the greatest $\mathrm{N}$ concentration (in stems, roots, and averaged in the plant)-greater than those grown in biocontainers fertilized with $15 \mathrm{~mm} \mathrm{~N}$ or
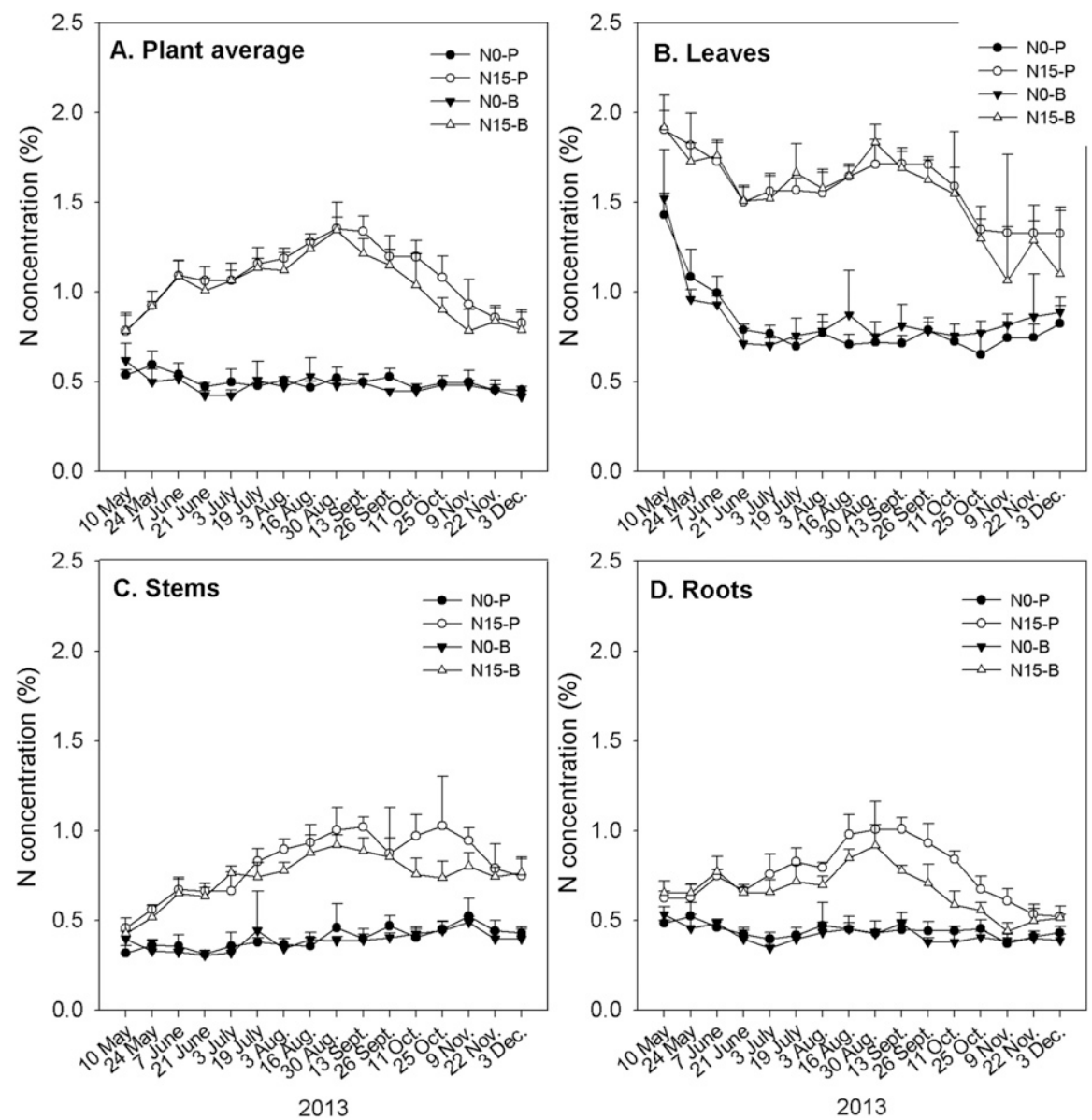

Fig. 4. Plant average $\mathrm{N}$ concentration $(\mathbf{A})$, or $\mathrm{N}$ concentration in leaves $(\mathbf{B})$, stems $(\mathbf{C})$, or roots $(\mathbf{D})$ of Encore ${ }^{\circledR}$ azalea 'Chiffon' fertilized with no $\mathrm{N}(\mathrm{N} 0)$ or $15 \mathrm{~mm} \mathrm{~N}(\mathrm{~N} 15)$ from $\mathrm{NH}_{4} \mathrm{NO}_{3}$ and grown in plastic containers (P) or paper biocontainers (B) over the 2013 growing season. Plants were harvested destructively and oven-dried biweekly from 10 May to 3 Dec. 2013. Nitrogen concentration was measured using the Kjeldahl method with $0.1 \mathrm{~g}$ dry sample. Error bars suggest SD. 
Tissue $N$ content. The $\mathrm{N}$ rate of $15 \mathrm{~mm} \mathrm{~N}$ resulted in greater $\mathrm{N}$ content than no $\mathrm{N}$ in leaves and the entire plant from 10 May to 30 Aug., in roots from 24 May to 13 Sept., and in stems for 10 harvests (Fig. 5). There was no difference in stem or root $\mathrm{N}$ content on 10 May between $\mathrm{N}$ rates. Plastic containers resulted in greater $\mathrm{N}$ content in leaves on 21 June, in roots on 24 May, and in the entire plant on 24 May and 21 June, but lower $\mathrm{N}$ content in roots on 7 June than biocontainers. The interaction between container type and $\mathrm{N}$ rate became significant later in the season, from 13 Sept. to 3 Dec. in leaves and the entire plant, from 26 Sept. to 3 Dec. in roots, and at five harvests (on 3 July, 26 Sept., 11 Oct., 9 Nov., and 3 Dec.) in stems. Regarding this interaction, plants grown in biocontainers had greater $\mathrm{N}$ content than those grown plastic containers when fertilized with $15 \mathrm{~mm} \mathrm{~N}$, with no difference between container types when plants received no N. At the end of the growing season on $3 \mathrm{Dec}$., biocontainers and $15 \mathrm{~mm} \mathrm{~N}$ resulted in an $\mathrm{N}$ content of 67.7 , 64.1, 31.3, and $163 \mathrm{mg} / \mathrm{plant}$ in leaves, stems, roots, and the entire plant, respectively, compared with an $\mathrm{N}$ content of 31.7 , 35.6, 14.4, and $81.7 \mathrm{mg} / \mathrm{plant}$, with plants
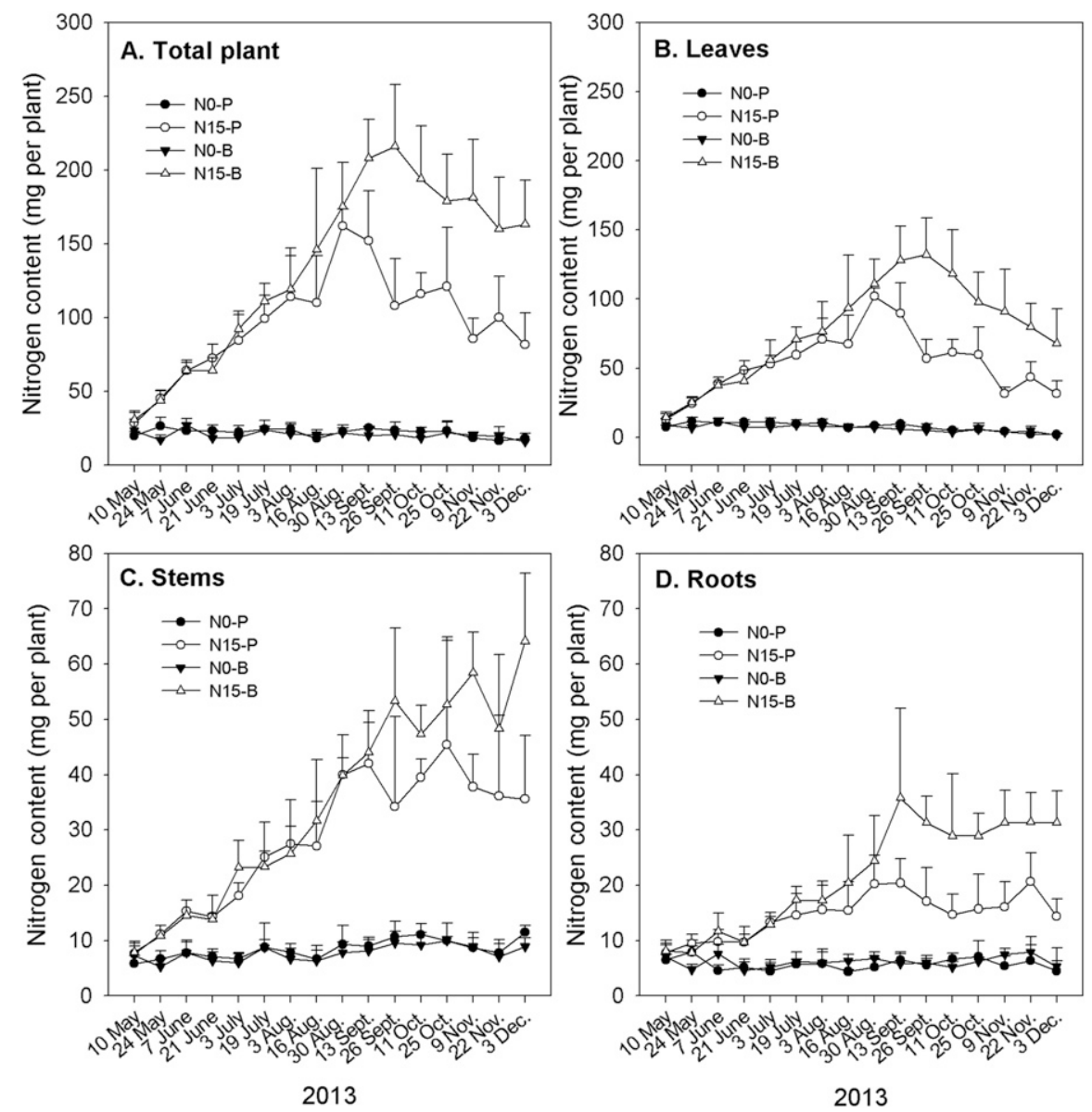

Fig. 5. Total plant $\mathrm{N}$ content $(\mathbf{A})$, or $\mathrm{N}$ content in leaves $(\mathbf{B})$, stems $(\mathbf{C})$, or roots $(\mathbf{D})$ of Encore ${ }^{\circledR}$ azalea 'Chiffon' fertilized with no $\mathrm{N}(\mathrm{N} 0)$ or $15 \mathrm{~mm} \mathrm{~N}(\mathrm{~N} 15)$ from $\mathrm{NH}_{4} \mathrm{NO}_{3}$ and grown in plastic containers (P) or paper biocontainers (B) over the 2013 growing season. Plants were harvested destructively and oven-dried biweekly from 10 May to 3 Dec. 2013. Nitrogen content was calculated by multiplying dry weight of the plant or each structure with their N concentration. Error bars suggest SD. grown in plastic containers ceased active growth or $\mathrm{N}$ uptake by the end of August.

Nitrogen uptake from fertilizer. Total $\mathrm{N}$ uptake from fertilizer of plants grown in plastic containers increased from $8.6 \mathrm{mg} /$ plant on 10 May to $139.2 \mathrm{mg} /$ plant on 30 Aug., sharing a similar trend in biocontainers that increased from $7.3 \mathrm{mg} / \mathrm{plant}$ on 10 May to $153.2 \mathrm{mg} / \mathrm{plant}$ on $30 \mathrm{Aug}$. (Fig. 6A). Nitrogen uptake from fertilizer in plants grown in plastic containers decreased after $30 \mathrm{Aug}$. from $126.9 \mathrm{mg} / \mathrm{plant}$ on $13 \mathrm{Sept}$. to $63.7 \mathrm{mg} /$ plant on $3 \mathrm{Dec}$. In comparison, $\mathrm{N}$ uptake from fertilizer of plants grown in biocontainers continued the increasing trend until 26 Sept., then decreased toward the end of the season, with $\mathrm{N}$ uptake from fertilizer ranging from 140.4 to $195.5 \mathrm{mg} /$ plant from 13 Sept. to 3 Dec. On average, biocontainers resulted in 57 to $111 \mathrm{mg}$ more $\mathrm{N}$ uptake from fertilizer per plant compared with plastic containers on a given date from 13 Sept. to 3 Dec. in plants fertilized with $15 \mathrm{~mm} \mathrm{~N}$.

Nitrogen uptake efficiency. The $\mathrm{N}$ uptake efficiency of plants grown in plastic containers and fertilized with $15 \mathrm{~mm} \mathrm{~N}$ increased from $2.71 \%$ on 10 May to $5.59 \%$ on 7 June and then remained between $5.15 \%$ and $5.70 \%$ from 21 June to 16 Aug. (Fig. 6B). The N uptake efficiency of plants grown in plastic containers peaked on Aug. 30 (6.96\%) and then decreased to $2.89 \%$ on $3 \mathrm{Dec}$. at the end of the growing season. The $\mathrm{N}$ uptake efficiency in plants grown in biocontainers and fertilized with $15 \mathrm{~mm} \mathrm{~N}$ increased from $2.32 \%$ on 10 May to $8.87 \%$ on 26 Sept., then started decreasing from 26 Sept. to 3 Dec. $(6.68 \%)$. The $\mathrm{N}$ uptake efficiency of biocontainer-grown plants increased during the period of 13 Sept. to 26 Sept., suggesting these plants were taking up $\mathrm{N}$ actively. However, the $\mathrm{N}$ uptake efficiency of plants grown in plastic containers decreased sharply after 30 Aug., suggesting these plants ceased active $\mathrm{N}$ uptake in September. The average $\mathrm{N}$ uptake efficiency of plants grown in biocontainers was generally greater than those grown in plastic containers from July 3 to Dec. 3.

Nitrogen uptake rate. In plants receiving no $\mathrm{N}$ from fertilizer, the $\mathrm{N}$ uptake rate ranged from -0.53 to $0.25 \mathrm{mg} \mathrm{N} / \mathrm{d}$ during the entire growing season regardless of container type (Fig. 6C). Using $15 \mathrm{~mm} \mathrm{~N}$, biocontainers resulted in $\mathrm{N}$ uptake rates of 0.55 and $0.73 \mathrm{mg} \mathrm{N} / \mathrm{d}$; plastic containers resulted in 0.60 and $0.98 \mathrm{mg} \mathrm{N} / \mathrm{d}$ on 24 May and 21 June, respectively. The $\mathrm{N}$ uptake rate of plants grown in biocontainers increased from 1.67 to $2.21 \mathrm{mg} \mathrm{N} / \mathrm{d}$ compared with 0.95 to $1.50 \mathrm{mg} \mathrm{N} / \mathrm{d}$ in plastic containers from 19 July to 13 Sept. With the last fertilization applied on 15 Sept., the $\mathrm{N}$ uptake rate of plants grown in both container types peaked on 13 Sept., then became negative from 11 Oct. to 3 Dec.

\section{Discussion}

Plastic containers resulted in comparable or greater PGI, dry weight, and N uptake of azalea 

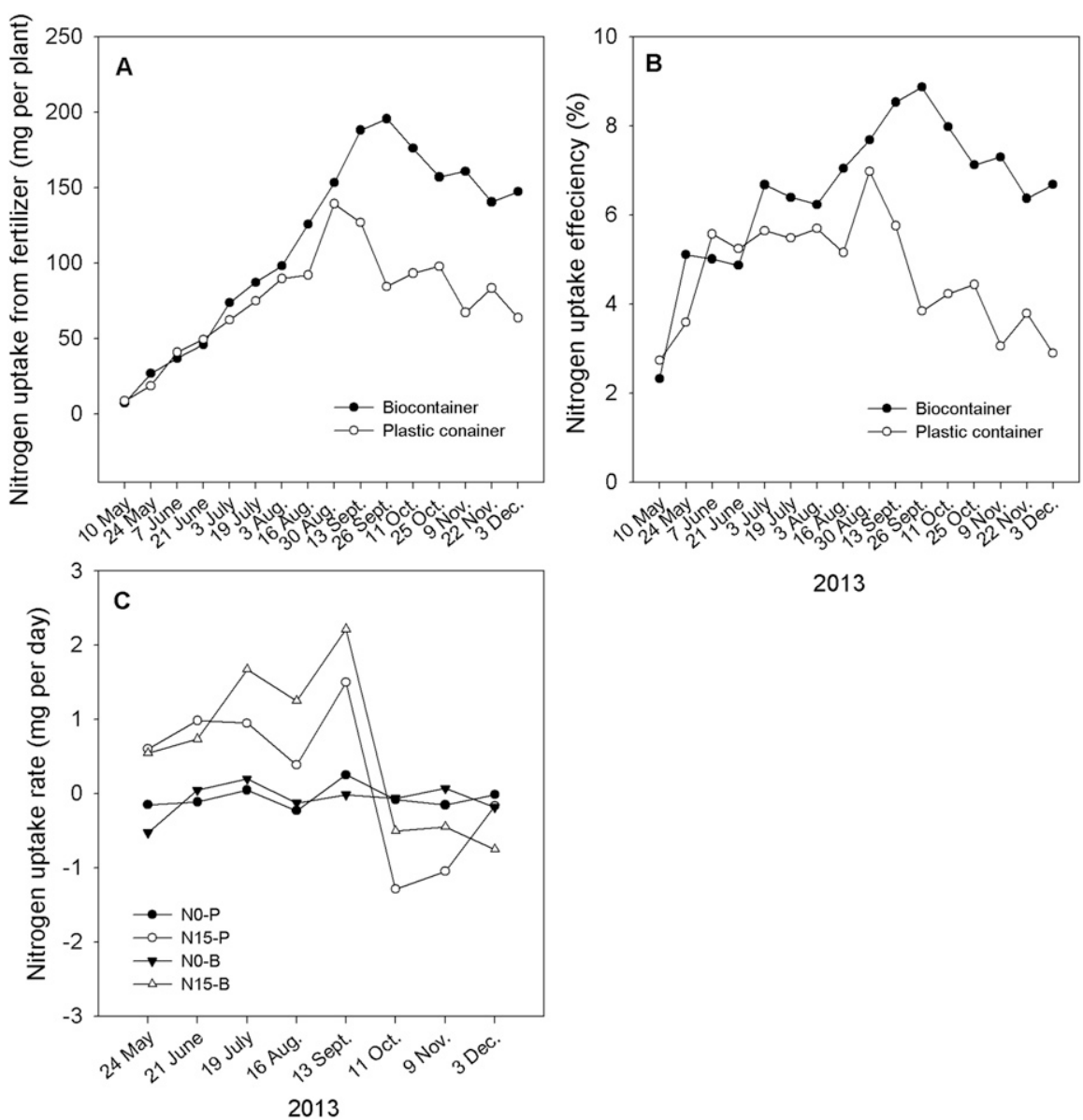

Fig. 6. Total $\mathrm{N}$ uptake from fertilizer (A), $\mathrm{N}$ uptake efficiency $(\mathbf{B})$, and $\mathrm{N}$ uptake rate $(\mathbf{C})$ of Encore ${ }^{\circledR}$ azalea 'Chiffon' plants fertilized with no $\mathrm{N}(\mathrm{N} 0)$ or $15 \mathrm{~mm} \mathrm{~N}(\mathrm{~N} 15)$ from $\mathrm{NH}_{4} \mathrm{NO}_{3}$ and grown in plastic containers (P) or paper biocontainers (B) over the 2013 growing season. Plants were harvested destructively and oven-dried biweekly from 10 May to 3 Dec. 2013 for N analyses. Nitrogen uptake rate was calculated on a 4-week interval and estimated as the average change in $\mathrm{N}$ content of the entire plant or each structure (leaves, stems, or roots) divided by the number of days in between. Nitrogen uptake from the fertilizer was estimated by subtracting total $\mathrm{N}$ content of plants fertilized with no $\mathrm{N}$ grown in a certain container type from the total $\mathrm{N}$ content of those receiving $15 \mathrm{~mm} \mathrm{~N}$ at each harvest. Nitrogen uptake efficiency (measured as a percentage) of plants fertilized with $15 \mathrm{~mm} \mathrm{~N}$ grown in a certain container type was calculated as the proportion of $\mathrm{N}$ uptake from fertilizer to the total applied $\mathrm{N}$ fertilizer on a given date. Nitrogen uptake rate (measured as milligrams per day) was calculated between two harvests and estimated as the difference in $\mathrm{N}$ content in a specific structure type or the entire plant divided by the number of days between the two harvests.

plant as biocontainers early in the season, with greater SPAD readings, dry weight (in leaves and roots), $\mathrm{N}$ concentration, and $\mathrm{N}$ content (in leaves and roots) than biocontainers at some harvests from May to August. This indicates plastic containers provided a similar or better growth environment compared with biocontainers during the time period. However, using $15 \mathrm{~mm} \mathrm{~N}$, biocontainers resulted in greater PGI, plant dry weight, and $\mathrm{N}$ content in the entire plant or in each structure type than plastic containers later in the season. Such a significant difference occurred in September on 13 Sept. or 26 Sept., and this trend remained to the end of the growing season on 3 Dec.

Sustainable alternative containers of various types have been reported to produce plants of similar quality compared with conventional plastic containers (Beeks and Evans, 2013; Koeser et al., 2013b; Kuehny et al., 2011; Li et al., 2015, 2019). Paper (also referred to as wood pulp) biocontainers pro- duced river birch (Betula nigra) plants of comparable PGI and plant biomass to plastic containers in a pot-in-pot production system (Li et al., 2015). Greater dry root weight of cyclamen (Cyclamen persicum) was found using paper and wood fiber containers compared with plastic containers (Beeks and Evans, 2013). The porous sidewall of the paper biocontainer used in the current study was found to increase water use as a result of water loss through the container sidewall (Nambuthiri et al., 2015; Wang et al., 2015), which reduced stomatal conductance and increased water stress of Hydrangea macrophylla in our previous study (Li et al., 2019). However, the evaporative cooling effect as a result of sidewall water loss may be beneficial for plant root growth and survival at locations with hot summer conditions (Nambuthiri et al., 2015). In addition, the lighter color of the paper biocontainer compared with black plastic may have also contributed to a lower substrate temperature from June to September, with a local average monthly temperature ranging from 70 to $80^{\circ} \mathrm{F}$ and a maximum air temperature greater than $90^{\circ} \mathrm{F}$ (U.S. Department of AgricultureNational Resources Conservation Service, 2018). Therefore, the increased evaporative cooling and lighter color of the paper biocontainer may have led to increased plant growth and $\mathrm{N}$ uptake of azalea plants, which benefits from well-drained substrate (Larson, 1993). In addition, September was the last month of the hottest period during 2013 at the experimental location. Considering that Encore $^{\circledR}$ azalea 'Chiffon' is one of the most dwarf cultivars in this branded serious and has a low growth rate, this might explain why a significant difference in plant growth and $\mathrm{N}$ uptake occurred late in the season in September.

In general, high rates of plant dry weight accumulation and $\mathrm{N}$ uptake occurred during the same time periods - from 21 June to 19 July and from 16 Aug. to 13 Sept.-in both container types. The consistent timing of fast dry weight accumulation and $\mathrm{N}$ uptake confirmed the theory that the growth rate of a given species is, to a large degree, the driving force of $\mathrm{N}$ uptake with sufficient $\mathrm{N}$ supply (Gastal and Lemaire, 2002). After 13 Sept., plants fertilized with $15 \mathrm{~mm} \mathrm{~N}$ grown in biocontainers had another flush of growth from 11 Oct. to 9 Nov, in terms of PGI and plant dry weight. Plants fertilized with the same $\mathrm{N}$ rate grown in plastic containers started to decrease in PGI and dry weight in September, resulting in the onset of significant differences in PGI, dry weight, and $\mathrm{N}$ content between container types. Besides the beneficial effects of evaporative cooling and light color, biocontainers also increased plant growth and $\mathrm{N}$ uptake by extending the active growth of azalea plants further into late fall in the current study.

The different growth pattern of plants grown in plastic containers and biocontainers requires different fertilization programs. Because fast $\mathrm{N}$ uptake was associated with plant biomass accumulation, sufficient fertilization should be applied at the times of active growth, when plants grown in biocontainers and plastic containers both had the two flushes of growth from 21 June to 19 July and from 16. August to 13 Sept. Although plastic container-grown plants ceased accumulating dry weight and $\mathrm{N}$ content after 13 Sept., biocontainer-grown plants had extended active growth to 9 Nov., in addition to the two flushes earlier in the season. Liquid feeding of fertilizer is usually ended by growers in September, which satisfies plastic container-grown plants because they had ceased fast $\mathrm{N}$ uptake by this time. Biocontainer-grown plants may require fertilization after September to support the final flush of growth. However, application of late-season fertilizer should be done with caution because it may stimulate tender new growth that might not be hardy enough to survive winter's freezing temperatures. 
Plant $\mathrm{N}$ uptake varies among species or cultivars and is affected by a series of growing conditions (Bi et al., 2007a; Gastal and Lemaire, 2002; Million et al., 2007). Under the experimental conditions in the current study, there was a lower $\mathrm{N}$ uptake rate and lower $\mathrm{N}$ uptake efficiency than those reported by $\mathrm{Bi}$ et al. (2007a). This is likely the result of two reasons: 1) the Encore ${ }^{\circledR}$ azalea 'Chiffon' used in this study is one of the most dwarf cultivars in the series and may have a lower growth rate compared with Rhododendron L. 'P.J.M.' and Rhododendron 'Cannon's Double' used in the study by Bi et al. (2007a); and 2) a greater N rate of $15 \mathrm{~mm}$ instead of $10 \mathrm{~mm}$ was applied to azalea plants in our study, resulting in lower $\mathrm{N}$ uptake efficiency. An N rate of $15 \mathrm{~mm}$ was used to ensure that $\mathrm{N}$ did not become a limiting factor for plant growth during the growing season. As for the container effect on $\mathrm{N}$ uptake, plastic containers resulted in greater $\mathrm{N}$ concentrations (in leaves, stems, roots, and averaged in the plant) than biocontainers during the entire growing season. However, biocontainers resulted in a greater $\mathrm{N}$ content than plastic containers from September to December, when plants were fertilized with $15 \mathrm{~mm}$ N. Increased N content in biocontainers resulted from greater plant dry weight than plants grown in plastic containers. The beneficial effect of biocontainers in increasing $\mathrm{N}$ uptake is through increasing plant dry weight, resulting in an increased amount of $\mathrm{N}$, but at similar or lower $\mathrm{N}$ concentrations in azalea plants as in plastic containers.

\section{Literature Cited}

Beeks, S.A. and M.R. Evans. 2013. Growth of cyclamen in biocontainers on an ebb-and-flood subirrigation system. HortTechnology 23:173176.

Bi, G., C.F. Scagel, L.H. Fuchigami, and R.P. Regan. 2007a. Differences in growth, and nitrogen uptake and storage between two container-grown cultivars of rhododendron. J. Environ. Hort. 25:13-20.

Bi, G., C.F. Scagel, L.H. Fuchigami, and R.P. Regan. 2007b. Rate of nitrogen application during the growing season alters the response of container-grown rhododendron and azalea to foliar application of urea in the autumn. J. Hort. Sci. Biotechnol. 82:753-763.

Bremner, J.M. 1965. Total nitrogen, p. 1149-1178. In: C.A. Black (ed.). Methods of soil analysis: Part 2: Agronomy. Soil Sci. Soc. Amer., Inc., Madison, WI.

Cardarelli, M., T. Rouphael, E. Rea, A. Salerno, and G. Colla. 2010. Nutrient solution concentration and growing season affect growth and quality of potted petunia in a recirculating subirrigation and drip-irrigation system. J. Food Agr. Environ. 8:312-320.

Chang, K.H., R.Y. Wu, G.P. Chang, T.F. Hsieh, and R.S. Chung. 2012. Effects of nitrogen concentration on growth and nutrient uptake of Anthurium andraeanum Lind. cultivated in coir under different seasonal conditions. HortScience 47:515-521.

Evans, M.R. and D. Karcher. 2004. Properties of plastic, peat, and processed poultry feather fiber growing containers. HortScience 39:10081011.

Evans, M.R., M. Taylor, and J. Kuehny. 2010. Physical properties of biocontainers for greenhouse crops production. HortTechnology 20:549-555.

Gastal, F. and G. Lemaire. 2002. N uptake and distribution in crops: An agronomical and ecophysiological perspective. J. Expt. Bot. 53:789-799.

Gómez-López, M.D., J.P. Fernández-Trujillo, and A. Baille. 2006. Cucumber fruit quality at harvest affected by soilless system, crop age and preharvest climatic conditions during two consecutive seasons. Scientia Hort. 110:68-78.

Hall, C.R., B.J. Campbell, B.K. Behe, C. Yue, R.G. Lopez, and J.H. Dennis. 2010. The appeal of biodegradable packaging to floral consumers. HortScience 45:583-591.

Koeser, A., G. Kling, C. Miller, and D. Warnock. 2013a. Compatibility of biocontainers in commercial greenhouse crop production. HortTechnology 23:149-156.

Koeser, A., S.T. Lovell, M. Evans, and J.R. Stewart. 2013b. Biocontainer water use in short-term greenhouse crop production. HortTechnology 23:215-219.

Kuehny, J.S., M. Taylor, and M.R. Evans. 2011. Greenhouse and landscape performance of bedding plants in biocontainers. HortTechnology 21:155-161.

Larson, R.A. 1993. Production of florist azaleas. Timber Press Growers Handbook Series. Vol. 6. Timber Press, Portland, OR.

Li, T., G. Bi, R.L. Harkess, G.C. Denny, E.K. Blythe, and X. Zhao. 2018. Nitrogen rate, irrigation frequency, and container type affect plant growth and nutrient uptake of Encore azalea 'Chiffon'. HortScience 53:560-566.

Li, T., G. Bi, R.L. Harkess, G.C. Denny, and C. Scagel. 2019. Nitrogen fertilization and irrigation frequency affect hydrangea growth and nutrient uptake in two container types. HortScience 54:167-174.

Li, T., G. Bi, G. Niu, S.S. Nambuthiri, R.L. Geneve, X. Wang, T. Fernandez, Y. Sun, and X. Zhao. 2015. Feasibility of using biocontainers in a pot-in-pot system for nursery production of river birch. HortTechnology 25:5762.
Mengel, K. and E.A. Kirkby. 2001. Principles of plant nutrition. 5th ed. Academic Publishers, London, UK.

Million, J., T. Yeager, and C. Larsen. 2007. Water use and fertilizer response of azalea using several no-leach irrigation methods. HortTechnology 17:21-25.

Nambuthiri, B., R.L. Geneve, Y. Sun, X. Wang, R.T. Fernandez, G. Niu, G. Bi, and A. Fulcher. 2015. Substrate temperature in plastic and alternative nursery containers. Hort Technology 25:50-56.

Pradubsuk, S. and J.R. Davenport. 2010. Seasonal uptake and partitioning of macronutrients in mature 'Concord' grape. J. Amer. Soc. Hort. Sci. 135:474-483.

Ristvey, A.G., J.D. Lea-Cox, and D.S. Ross. 2007. Nitrogen and phosphorus uptake efficiency and partitioning of container-grown azalea during spring growth. J. Amer. Soc. Hort. Sci. 132:563-571.

Scagel, C.F., G. Bi, L.H. Fuchigami, and R.P. Regan. 2007. Seasonal variation in growth, nitrogen uptake and allocation by containergrown evergreen and deciduous rhododendron cultivars. HortScience 42:1440-1449.

Scagel, C.F., G. Bi, L.H. Fuchigami, and R.P. Regan. 2011. Effects of irrigation frequency and nitrogen fertilizer rate on water stress, nitrogen uptake, and plant growth of containergrown rhododendron. HortScience 46:15981603.

Strik, B.C. and D.R. Bryla. 2015. Uptake and partitioning of nutrients in blackberry and raspberry and evaluating plant nutrient status for accurate assessment of fertilizer requirements. HortTechnology 25:452-459.

U.S. Department of Agriculture, National Agricultural Statistics Service. 2016. Floriculture Crops 2015 Summary. 10 Dec. 2018. <https:// downloads.usda.library.cornell.edu/usda-esmis/ files/0p0966899/pz50gz655/8910jx14p/FlorCrop04-26-2016.pdf $>$.

U.S. Department of Agriculture, National Resources Conservation Service. 2018. Report Generator 2.0. 9 Dec. 2018. <https://wcc.sc. egov.usda.gov/reportGenerator/edit/customMulti TimeSeriesGroupByStationReport/daily/start_of_ period/NONE/0,0/NONE? fitToScreen=false $>$.

Wang, X., R.T. Fernandez, B.M. Cregg, B. Auras, A. Fulcher, D.R. Cochran, G. Niu, Y. Sun, G. Bi, S. Nambuthiri, and R.L. Geneve. 2015. Multistate evaluation of plant growth and water use in plastic and alternative nursery containers. HortTechnology 25:42-49.

White, J.D. 2009. Container ecology. GrowerTalks 72:60-63.

Wilson Bros. Gardens. 2018. Encore azaleas. 12 Dec. 2018. <http://www.wilsonbrosonline.com/ Plants/Shrubs/Encore-Azaleas.aspx>. 